\title{
PARKING SPACE PERFORMANCE EVALUATION IN GENERAL HOSPITAL CITY IBNU SINA GRESIK
}

\author{
Hadi Prasetiya ${ }^{1}$, \\ ${ }^{1}$ Students of the Faculty of Engineering, Department of Civil Engineering, \\ University of Narotama \\ hadiprasetiya652@gmail.com \\ Sri Wiwoho Mudjanarko \\ ${ }^{2}$ Lecturer Faculty of Engineering, Department of Civil Engineering, \\ University of Narotama \\ Jl Arief Hakim Rachaman 51, 60117
}

\begin{abstract}
Parking is one element means that can not be separated from road transport system as a whole. Parking is a problem that is often encountered in the urban transport system both in major cities and in the growing city. Parking problems are also a thing that can not be handled several hospitals. The number of hospital facilities will encourage people to visit the hospital. The purpose of this study was to analyze the needs of a parking space, to determine the pattern of the corresponding parking space is used in a general hospital Avicenna. The method applied in this research is to conduct a survey directly in the field include admission-out to get the data of the vehicle. Analysis of vehicle data to get a parking volume, accumulation, The results of the analysis obtained by the characteristics of parking for 2-wheel vehicles and wheels 4 have the highest volume in a row parking for 679 vehicles and 120 vehicles.
\end{abstract}

Keywords : Parking, parking requirement, Hospitals

\section{INTRODUCTION}

The existence of the hospital is needed to tackle health problems in the community. Hospitals provide health services to the community and has a very important role in accelerating the improvement of people's health. General Hospital Ibnu Sina Gresik Hospital is one of the largest of the many Hospitals in Gresik. Ibn Sina Hospital of Gresik serve patients in addition to general and special also serve patients Askes, JAMKESMAS, and BPJS. This is why the General Hospital Ibn Sina Gresik is visited patients who want treatment. From year to year public visits to public hospitals Ibnu Sina Gresik increasing it makes increasing use of private vehicles either cars or motorcycles as a means of transportation to the hospital.

The need for the fulfillment of the parking spaces at Ibn Sina Hospital in the city of Gresik become a very important issue to be addressed as access to the lbn Sina Hospital of Gresik is supposed freeway from vehicles parked on the road. The number of health facilities and personnel at Ibn Sina Hospital of Gresik into him as one of the most active hospital in the city of Gresik in serving patients. The land area of Ibnu Sina Hospital of Gresik $50,000 \mathrm{~m} 2$ with a building area of $36,000 \mathrm{~m} 2$ and parking for two-wheeled land of $900 \mathrm{~m} 2$ and $1,280 \mathrm{~m} 2$ on four wheels.

In the "Spatial Analysis of Gorontalo City Center Central Market" Lydia Surijani Tatura (2015) said the parking issue is very important to be examined more deeply, because almost all activities require a means activity room is open parking lot. (Tatura, 2015)

To overcome this certainly needs to be done on the parking performance 
evaluation of current conditions as an idea to plan ahead, so that we no longer encounter a vehicle that does not get a parking spot. This course also aims to realize the convenience and neatness parking in Ibn Sina Hospital of Gresik.

\section{Understanding Hospitals}

The hospital is a health care instituti provesional that His ministry is provided by doctors, nurses and other health professionals.

a. Types of Hospital

- $\quad$ General Hospital

Serving nearly alldiseasegeneral and emergency care institutions typically have a 24-hour (emergency room) to address the dangers in time as soon as possible and provide first aid.

\section{- $\quad$ Specialized hospital}

This type of covertrauma center,nursing center, Hospitals, seniors, or hospitals that serve special interests such aspsychiatric(psychiatric hospital) disease respiration, and others. Hospitals can consist of any combination or just onebuilding,

\section{- Hospital research / education}

Hospital research / education is a public hospital associated with research and education activities in the faculty of medicine at a university / higher education institution. Usually this hospital used for the training of young doctors, testing a wide range of new drugs or new treatments. The hospital is organized by the university / college as a form of devotion the society / Tri Dharma college.

- Hospital institution / company

The hospital founded by an agency / company to serve patients who are members of the institution / company's employees. The reason could be due to the establishment of diseases related to the activities of these institutions (eg military hospitals, airports), the form of social security / free treatment for employees, or because the location / remote company locations / away from the general hospital. Usually hospital institutions / companies in Indonesia also received a public patient and provide the emergency room to the general public.

\section{- Clinic}

A clinic (or an outpatient clinic or ambulatory care clinics) is a health care facility dedicated to the care of outpatients. The clinic can be operated, managed and funded privately or publicly, and typically include primary health care needs of the population in the local community, in contrast to a larger hospital that offers specialized care and admit patients hospitalized for an overnight stay.

\section{Understanding Parking}

In Article 1 paragraph 5 of Law No. 22 Year 2009 regarding Traffic and Road Transportation.Parking is keadadan not move a vehicle that is temporary since abandoned by the driver.(DPR 2009) Another notion is taken from Gresik 
Regent Regulation No. 31 of 2016. Article 1 states that parking is keaadaan vehicle stops or does not move for a few moments and left the driver, while the parking area is a vehicle stops at the specified location that is common to the curb or road including the parking lot is not fixed or parking of vehicles on the road regularly or routinely same location or place outside the road which is a public parking falilitas include private parking lot and day care centers that charge a particular vehicle. (Gresik, 2016)

Basis of the park is the Decree of the Minister of Transportation No. KM 66 of 1993 regarding parking facilities for the General and the Decree of the Minister of Transportation Number KM 4 of 1994 on how the parking of vehicles on the road has arranged parking facilities for the public and procedures for on-street parking, with Decision Director General of Land No. 272 / HK.105 / DrJD / 96.(Transportation, 1996)

Parking is a requirement for vehicle owners want their vehicles and park in a place, where it is easy to accomplish.

\section{Types of Parking}

- According Parking The placement

a) Parking on the street (on-stereet parking) parking is by using the road as a parking lot.

b) Off-street parking (off-street parking) parking is off-street vehicle can be in the courtyard office building, supermarket, or in a garden park.

- According to park status

a) Public parking

Public parking is parking the use of land, streets and squares that have / controlled and managed hosted by the regional administration.

b) Special parking Special parking is the parking that use lands that are not owned / controlled by the local government, the management organized by other parties in the form of business entities and individuals.

c) Emergency Parking / insedentil

Emergency Parking / insedentil is parking in public places either use the land, roads, fields belonging to local governments or private Gresik because insedentil.

d) Amusement park

Amusement park is an area of the parking building incorporating parking advice, the management facilitation Held by local governments Gresik.

e) Parking lot

The parking deck is a building that is used for the parking of vehicles which operate by the local government or third parties have obtained permission from the local government of Gresik.

- Parking By Vehicle

a) No motorized vehicles (bicycles)

b) Motorcycle

c) Car

- Parking by Type Purpose Center

a) Parking passengers, to raise and lower passenger needs.

b) Parking goods, for loading and unloading requirements. 
- Parking by Type of Ownership and Operation

a) Privately owned and managed by the private sector

b) Local government owned and managed by local governments

c) Local government owned and managed by private

\section{Patterns Parking}

To carry out a policy with parking, parking is first thought patterns that will be implemented. Parking pattern that has evolved as follows:

- The pattern of parallel parking

Parallel parking is a way parallel parking of vehicles on the roadside, generally a parking facility that is normally applied in the city center, or in neighborhoods that do not have a garage

- The pattern of angled parking

In principle, the size of an angled parking markers did not differ with parallel parking, but the difference is only the arrangement of the position of the vehicle.

\section{Unit Space Center}

Unit Space Center or the abbreviated SRP is the effective area to put a vehicle, in this case a passenger car, bus / truck or motorcycle, both parallel parking lane road, parking lot or parking building. SRP should consider free space and wide opening doors. In a controlled parking lot will require markings on the road surface to facilitate the activities of the park itself. Additional space is needed to perform motion control, where it depends on the angle parking.(DIRECTORATE GENERAL OF TRANSPORTATION ROAD, nd)

Parking angle is determined based on the following considerations:

- Safety, order and smooth traffic.

On the streets whose width is less, only capable of parallel parking that can be used, because the parking lot is precisely that angle is less secure than with the use of parallel parking for an area that has a high enough speed. Parking is allowed only on the angular capacity of the roads are wide local collectors and sufficient capacity.

- The road condition and environment.

The greater the angle used, the smaller the area of each parking space, but more broadly paths that are needed to make a circle to turn to the parking attendant to occupy the parking lot.

\section{Data collection}

\section{RESEARCH METHODS}

a. Primary data

Is data obtained by the survey directly into the field on the survey can be obtained from the data that is in the field and the real conditions in the study areas.

\section{b. Secondary data}

Data retrieval is done in cooperation with related government agencies. The secondary data is needed: 
a) Spacious parking lot at the General Hospital Ibn Sina Gresik.

b) The number of visitors who came to the General Hospital Ibn Sina Gresik

\section{Method of collecting data}

In this study using multiple data collection techniques:

a) Observations or observation to observation of physical condition and activity at the study site

b) Interview or question and answer directly to the respondent or informant

c) Documentation refers to the gathering and assessment of some information

\section{Data management}

After collecting the data we then do pengelolahan data. The steps will be undertaken as follows:

a) Data Selection

Stages of data management by re-examining the data obtained, if it is appropriate to the subject matter.

b) Data Klerifikasi

Classify the data obtained with the subject sesiuai or problems in stacking.

c) Compilation of data

Systematically compiling data by making it easy to sort order in the analysis

\section{RESULTS AND DISCUSSION}

\section{Length Parking}

The calculation is performed by classifying a vehicle in a given time interval. The interval is the duration of the vehicle, each vehicle are grouped in one interval corresponding to the duration of the parking lot. Grouping is done by creating a table.

Calculation of Data Adequacy Test Center On Tuesday:

The amount of data $(\mathrm{n}) \quad=564$ Vehicles

Data smallest

World Data

Total class (Jk)

Classrooms (Rk)

The length of the class

$=1$ minute

$=480$ minutes

$=1+3.3 \log n=1+3.3 \log 564=10.07=$ 10 class

$=480-1=479$ minutes

$=\mathrm{Rk} / \mathrm{Jk}=479 / 10=47.9=48$ minutes

Table 1. Adequacy test vehicle on a Tuesday 
Information:

Source: survey Results and calculations

\begin{tabular}{|c|c|}
\hline $\begin{array}{l}X i \\
2\end{array}$ & $=$ Midpoint Interval class $=$ Lower class limits + upper class limits \\
\hline $\mathrm{Fi}$ & Class $=$ Frequency \\
\hline & $=$ Average-the average amount Data has been grouped \\
\hline & $\sum_{i=1}(\mathrm{Xi} . \mathrm{Fi})=76254 / 564=135.2021=135$ minutes \\
\hline & $\left.=\sqrt{ } \sum_{i=1}(X i-X), \mathrm{Fi}\right) /\left(\sum \mathrm{fi}-1\right)=$ standard deviation \\
\hline b & $\begin{array}{l}=\sqrt{ } \quad 11969700.5 /(564-1)=6.1451 \\
=10 \% \times 135=13.5\end{array}$ \\
\hline
\end{tabular}

(A) $95 \%(Z \alpha / 2=1.96)$ of the normal distribution table

$$
\begin{aligned}
& n \geq(Z \alpha / 2) 2 .(\Sigma x) 2) / b 2 \\
& n \geq(1.96 \times 6.1451) 2 /(26.5) 2 \\
& n \geq 145.06 / 702.25 \\
& 464 \geq 0.2065 \ldots . .0 k !
\end{aligned}
$$

Table 2. Total Data Vehicle

\begin{tabular}{|c|c|c|c|c|c|c|}
\hline $\begin{array}{c}\text { Interval } \\
\text { (minute) }\end{array}$ & $\begin{array}{c}\mathrm{Xi} \\
\text { (minute) }\end{array}$ & $\begin{array}{c}\mathrm{Fi} \\
\text { (vehicle) }\end{array}$ & $\begin{array}{c}\text { Xi.Fi } \\
\text { (Kend.menit) }\end{array}$ & $X i-X$ & $(X i-X)^{2}$ & $\mathrm{Fi}(\mathrm{Xi}-\mathrm{X})^{2}$ \\
\hline $1-52$ & 26.5 & 130 & 3445 & $\begin{array}{c}- \\
103.5\end{array}$ & 10712.25 & 1392592.5 \\
\hline 53-104 & 78.5 & 117 & 9184.5 & -38.5 & 1482.25 & 173423.25 \\
\hline 105-156 & 130.5 & 90 & 11745 & 40.5 & 1640.25 & 147622.5 \\
\hline $157-208$ & 182.5 & 102 & 18615 & 80.5 & 6480.25 & 660985.5 \\
\hline $\begin{array}{l}209- \\
260\end{array}$ & 234.5 & 45 & 10552.5 & 189.5 & 35910.25 & 1615961.25 \\
\hline 261-312 & 286.5 & 19 & 5443.5 & 267.5 & 71556.25 & 1359568.75 \\
\hline $313-364$ & 338.5 & 11 & 3723.5 & 327.5 & 107256.25 & 1179818.75 \\
\hline $365-416$ & 390.5 & 18 & 7029 & 372.5 & 138756.25 & 2497612.5 \\
\hline 417-468 & 442.5 & 8 & 3540 & 434.5 & 188790.25 & 1510322 \\
\hline $469-520$ & 494.5 & 6 & 2967 & 488.5 & 238632.25 & 1431793.5 \\
\hline & $\Sigma$ & 546 & 76245 & & $\Sigma$ & 11969700.5 \\
\hline
\end{tabular}

\begin{tabular}{ccc}
\hline Day & Tuesday & Friday \\
\hline Total Data (Vehicle) & 564 & 679 \\
$\Sigma x$ & 6.1451 & 6.7532 \\
Minimum Data & .2065 & .2494 \\
Vehicle & & \\
\hline
\end{tabular}

After the calculation of the adequacy of test data, we can calculate the duration of each type of cars and motorcycles. From these calculations take a sample of that Tuesday.

For these types of automobiles on Tuesday:

Vehicle number $(n) \quad=93$ vehicles 
Smallest Data

Largest Data

Number of Classes (Jk)

Classroom (Rk)

Length Grade (Pk)

$$
\begin{aligned}
& =1 \text { minute } \\
& =321 \text { minutes } \\
& =1+3.3 \log 321=9.2715=10 \text { class } \\
& =321-1=320 \text { minutes } \\
& =\mathrm{Rk} / \mathrm{Jk}=320 / 10=32 \text { minutes }
\end{aligned}
$$

Table 3. Car adequacy test

Source: Survey Results and Calculation

\begin{tabular}{cccc}
\hline $\begin{array}{c}\text { interval } \\
\text { (minute) }\end{array}$ & $\begin{array}{c}\text { Interval } \\
\text { (minute) }\end{array}$ & $\begin{array}{c}\text { Interval } \\
\text { (vehicle) }\end{array}$ & $\begin{array}{l}\text { Interval } \\
\text { (Kend.minute) }\end{array}$ \\
\hline $1-32$ & 16.5 & 27 & 445.5 \\
$33-64$ & 48.5 & 15 & 727.5 \\
$65-96$ & 80.5 & 8 & 644 \\
$97-128$ & 112.5 & 11 & 1237.5 \\
$129-160$ & 144.5 & 7 & 1011.5 \\
$161-192$ & 176.5 & 6 & 1059 \\
$193-224$ & 208.5 & 9 & 1876.5 \\
$225-256$ & 240.5 & 3 & 721.5 \\
$257-288$ & 272.5 & 5 & 1362.5 \\
$289-320$ & 304.5 & 2 & 609 \\
& $\Sigma$ & 93 & 9694.5 \\
\hline
\end{tabular}

$X=9694.5 / 93=104.2419=105$ minutes

For this type of motorcycle on Tuesday in the parking lot I:

The number of vehicles $(n)=125$ Vehicles

Data smallest

World Data

$=3$ minutes

$=497$ minutes

Total class (Jk)

Classrooms ( $\mathrm{Rk})$

$=1+3.3 \log 225=8.7622=8$ classes

$=497-3=494$ minutes

The length of the class $(\mathrm{Pk})=\mathrm{Rk} / \mathrm{Jk}=494 / 8=61.75=62$ minutes

Table 4. Length Parking Motorcycle On Tuesday in the parking lot I:

\begin{tabular}{cccc}
\hline $\begin{array}{c}\text { interval } \\
\text { (minute) }\end{array}$ & $\begin{array}{c}\mathbf{X i} \\
\text { (minute) }\end{array}$ & $\begin{array}{c}\mathbf{F i} \\
\text { (vehicle) }\end{array}$ & $\begin{array}{c}\mathbf{X i . F i} \\
\text { (Kend.menit) }\end{array}$ \\
\hline $1-62$ & 31.5 & 105 & 3307.5 \\
$63-126$ & 94.5 & 6 & 567 \\
$127-188$ & 157.5 & 5 & 787.5 \\
$189-250$ & 219.5 & 7 & 1536.5 \\
$251-312$ & 281.5 & 2 & 563 \\
$313-374$ & 343.5 & 0 & 0 \\
$375-436$ & 405.5 & 0 & 0 \\
$437-498$ & 467.5 & 0 & 0 \\
\hline & $\Sigma$ & 125 & 6761.5
\end{tabular}

Source: Survey Results and Calculation

$X=6761.5 / 125=54.092=54$ minutes

For the types of vehicles motorcycles on Tuesday in the parking lot II:

The number of vehicles $(n)=339$ vehicles

Data smallest $\quad=1$ minute 
World Data

Total class (Jk)

Classrooms (Rk)

The length of the class $(\mathrm{Pk})=\mathrm{Rk} / \mathrm{Jk}=492 / 9=54.6667=55$ minutes

$$
=493 \text { minutes }
$$$$
=1+3.3 \log 493=9.8864=9 \text { class }
$$

$=493-1=492$ minutes

Table 5. Duration motorcycle parking on Tuesdays in the parking lot II:

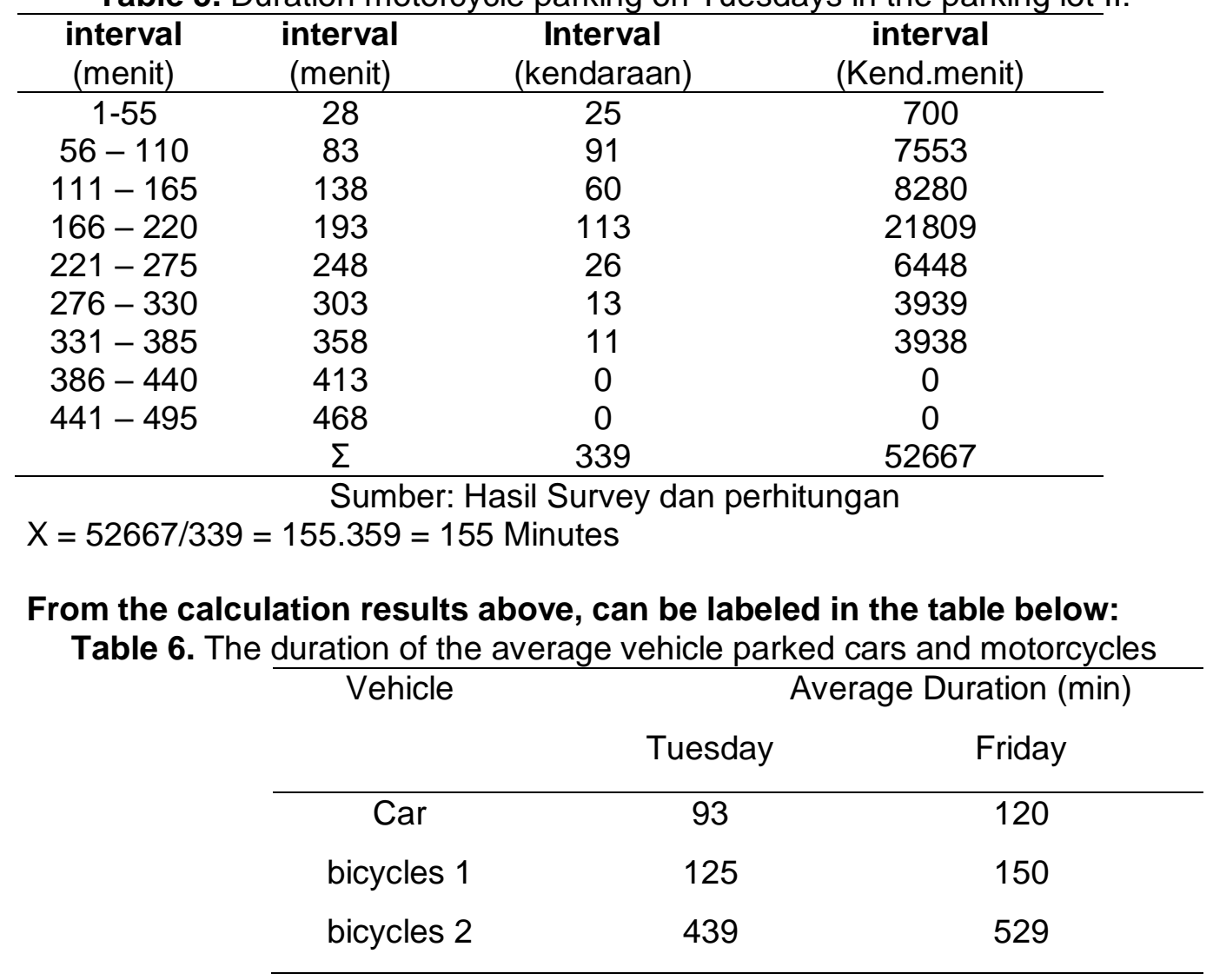

Time parking duration in minutes

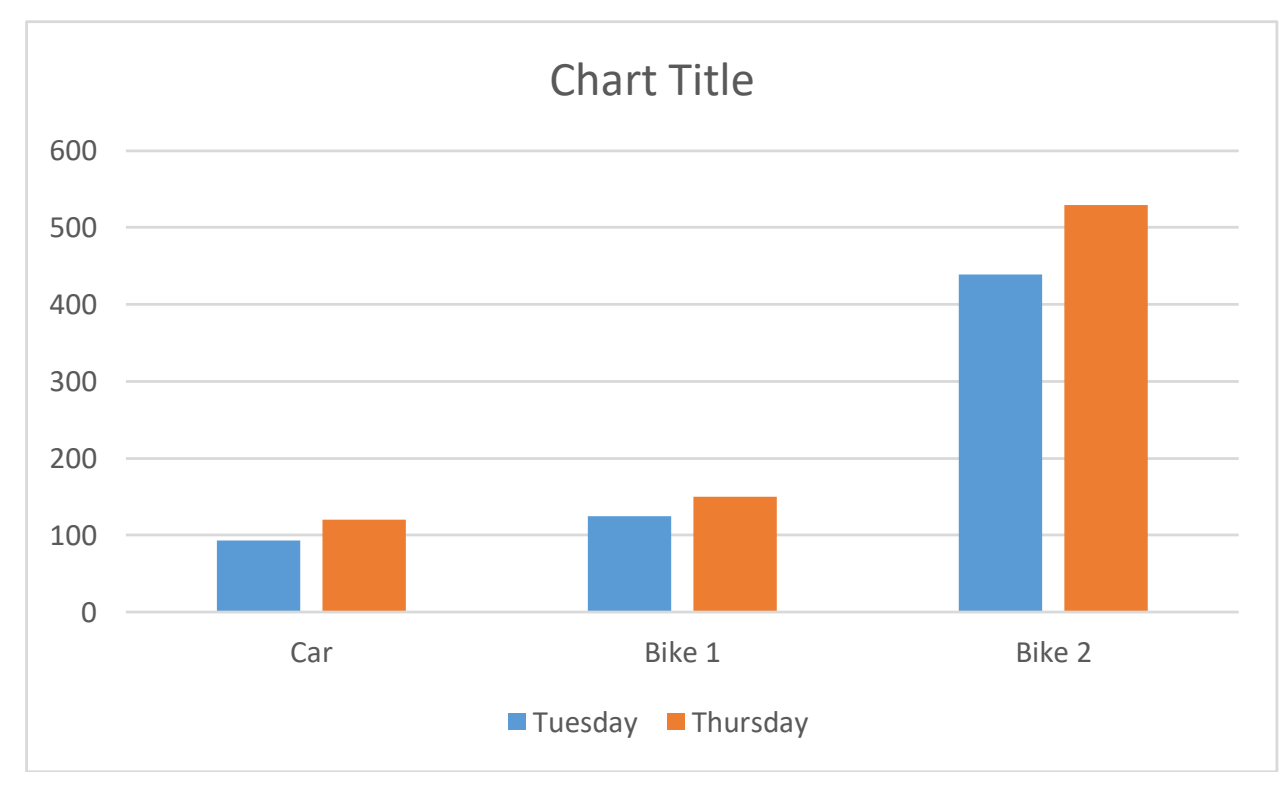


Figure 1. Diagram average duration Parking

From the table above picture there are differences and average duration far enough between a motorcycle parked in the first land on a motorcycle parked in the area II and the difference with a different day.

\section{CONCLUSIONS}

Based on the analysis and the above discussion regarding the need for parking spaces at the General Hospital Ibn Sina, the authors draw the following conclusion:

- Accumulated maximum parking in the parking lot of Ibn Sina Hospital for 2-wheel vehicles amounted to 185 vehicles took place at 09:00 to 10:00 pm and 4-wheel vehicle is 60 vehicles which took place at 10:00 to 11:00 $\mathrm{pm}$;

- The parking spaces General Hospital Ibn Sina can only accommodate 2wheel vehicles with a capacity of 160 vehicles and 4-wheel vehicle 50 that it can not accommodate vehicles with a capacity of 2-wheel vehicles parking senbanyak 185 vehicles / hour and 4-wheel vehicles to 60 vehicles / hour;

\section{REFERENCE}

DIRECTORATE GENERAL LAND TRANSPORTATION. (Nd). GUIDELINES FOR PLANNING AND OPERATION OF PARKING FACILITIES.

Fahmi, K. (2014). Analysis of the parking space capacity of the modern market. APTEK Journal, 6 (1), 107-116.

Fauziah Syarifuddin. (2017). PARKING SPACE NEEDS IN THE CITY Police Hospitals in MAKASAR. Makassar.

Gresik, B. (2016). EAST JAVA PROVINCE.

Ibrahim, DM, Walujodjati, E., \& Ismail, A. (nd). Public Space Utilization Study For Parking Lot. On the Road Cikuray Garut, 11.

Ismiyati. (2004). DETERMINATION OF NEEDS ASSESSMENT STANDARD PARKING SPACES, 12 (3), 49-59.

Joko Suprianto, Sri Wiwoho Mudjanarko. (2015). The performance evaluation of parking in Surabaya Hajj rsu 1, 1, 1-10.

Kasan, M. (2010). Parking Space Needs Model Trading Business Unit Clothing in Palu. SMARTek Journal, 8 (1), 13-21.

Kusyanto, M. (2005). Studies sultan Fatah university parking space (unisfat) Demak, (83), $12-24$

Lumba, P., \& Lock, K. (nd). Parking Space Needs Analys is in Pasar Muara Rumbai NEEDS ANALYSIS OF PARKING SPACES IN THE MARKET MUARA tassel SAND Pengaraian, 121-126.

luqman Assaffat. $(\mathrm{Nd})$. The design of the parking system.

Parliament, R. (2009). LAW - LAW OF THE REPUBLIC OF INDONESIA NUMBER 22 OF 2009.

Prasetiyo, James A. Timboeleng, HP (2014). Analysis of the parking space requirements in the area of trade center city tomohon, 6 (3), 333-340.

Priambodo, Aditya W. (2013). Analysis Curbside Parking Management Works in Semarang City Year 2012-2013, (14010110130095), 1-26. 
R, NW, Sulistio, H., Suharyanto, A., Ranch, F., Engineering, F., Mathematics and Natural Sciences, F., \& Agriculture, FT (nd). Evaluation of Needs A Parking Space On The Campus Brawijaya University Campus of Brawijaya University). To, 13, 79-90.

Saputra, ID (2013). Levy Management Analysis Center In Makassar.

Sari, RM (2014). State Polytechnic of Sriwijaya. Identification Pulse Through the Leaves Ear Using Pulse Sensor, 1 (2), 55. https://doi.org/10.1016/j.ijhydene.2009.08.032

Sri Wiwoho Mudjanarko, Tubagus Purworusmiardi (2017). Applocation of Radio Frequency Identification System for Supporting the Performance of Motorcycle Parking in Narotama University

Sukmana, WI, \& Kurniawan, C. (nd). Automatic Parking System Design Portal With Marker Counter As Atmega Microcontroller-Based Parking Lot 16.

Suthanaya, PA (2010). Characteristics Analysis And Parking Space Needs At Shopping Center in Badung regency. Scientific Journal of Civil Engineering, 14 (1), 10-19.

Tatura, L. (2015). Spatial Analysis Central Market Parking Gorontalo.

Transportation, D. (1996). Technical guidelines.

Yudi Yuniarto Adi, Bambang Pudjianto, Rina Syamsurizal, ABS (2014). Diponegoro University, 1-6.

Wardhanto Dian Arifin Ilham Chandra Feriawan, Djoko Purwanto, KHB (2017). Based on Government Regulation, 2013, 29-44. 